Sławomir BRALEWSKI*

\title{
HIERARCHIA WSCHODNICH BISKUPÓW W HISTORIOGRAFII KOŚCIELNEJ V WIEKU
}

Sam termin „hierarchia” można rozumieć różnorako. Wywodzi się on od

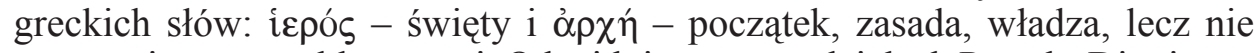
występuje w grece klasycznej. Odnajdujemy go w dziełach Pseudo-Dionizego Areopagity, prawdopodobnie syryjskiego mnicha żyjącego na przełomie V i VI wieku, który użył go dla określenia porządku, jakiemu podlegają aniołowie oraz opisania ładu strukturalnego panującego w Kościele. Trzeba jednak zaznaczyć, że Pseudo-Dionizy pojmował hierarchię szeroko i wzniośle, ulegając wpływowi kosmicznego gradualizmu bytowego charakterystycznego dla neoplatonizmu. Pisał bowiem:

„Hierarchia jest, jak ją rozumiem, świętym porządkiem i wiedzą, i działalnością, upodabniającą się - tak dalece, jak to możliwe - do boskiej formy, i wznosi się do naśladowania Boga proporcjonalnie do oświecenia, które jest jej przekazywane przez samego Boga"”.

Dla potrzeb niniejszych rozważań rozumiał będę hierarchię wedle definicji słownikowej, określającej ją jako „ustopniowany układ”2, w tym wypadku obejmujący biskupów, ale na tym najwyższym szczeblu - bez wzajemnego podporządkowania i zależności, na zasadzie primus inter pares. Wszak z punktu widzenia łaski episkopalnej biskupi są sobie równi. Tak zawężone pole semantyczne hierarchii bliskie więc będzie pojęciu ,precedencji” rozumianemu jako porządek pierwszeństwa. Dziś kwestie te rozstrzyga protokół dyplomatyczny. W kanonach soborowych zajmujących się sprawą pierwszeństwa w Kościele użyte są terminy $\pi \rho \omega \tau \varepsilon \hat{\imath} o v$ (pierwszeństwo, przewodnictwo) i $\pi \rho \varepsilon \sigma \beta \varepsilon i \alpha$ (starszeństwo). Sformułowana w 6. kanonie Soboru Nicejskiego (325) zasada pierwszeństwa brzmi:

* Dr hab. Sławomir Bralewski, prof. UŁ - profesor nadzwyczajny w Katedrze Historii Bizancjum w Instyucie Historii na Wydziale Filozoficzno-Historycznym Uniwersytetu Lódzkiego; e-mail: sbralewski@o2.pl.

${ }^{1}$ Ps-Dionysius Areopagita, De coelesti hierarchia III 1, SCh 58bis, 87, tłum. M. Dzielska: Hierarchia niebiańska, w: Pseudo-Dionizy Areopagita, Pisma teologiczne, Kraków 2005, 83.

${ }^{2}$ M. Szymczak, Stownik języka polskiego, t. 1, Warszawa 1995, 694. 
„niech będzie zachowywane w Kościołach pierwszeństwo wynikające ze starszeństwa"3.

W ramach prowadzonych tutaj rozważań interesować mnie będą poglądy poszczególnych autorów Historii kościelnych z V wieku na temat biskupstw uznawanych przez nich za najważniejsze, oraz miejsce, jakie skłonni byli im przyznać w Kościele powszechnym. Szczególną uwagę poświęcę więc różnorakim zestawieniom czy listom zwierzchników kościelnych ułożonym przez wspomnianych historyków. Istotna dla moich rozważań będzie kolejność, w jakiej ci wymienili poszczególnych biskupów. Postaram się dociec przyczyn, które miały na nią wpływ, rozważając, na ile zasada dostosowywania organizacji kościelnej do podziału politycznego, zwana zasadą akomodacji współgrała w Historiach kościelnych, z zasadą sukcesji apostolskiej.

Francis Dvornik (1893-1975) wyraził pogląd, że we wschodniej części cesarstwa dominowała zasada akomodacji nad zasadą apostolskiego pochodzenia, gdyż znajdowało się tam nazbyt wiele stolic biskupich założonych czy związanych w jakiś sposób z Apostołami ${ }^{4}$. Czy twierdzenie czeskiego badacza znajduje uzasadnienie $\mathrm{w}$ precedencji biskupów stosowanej w greckiej historiografii kościelnej $\mathrm{V}$ wieku? $\mathrm{Na}$ to pytanie spróbuję udzielić odpowiedzi.

1. Euzebiusz z Cezarei (ok. 260-340). Ponieważ autorzy Historii kościelnych pisanych w V wieku kontynuowali Historię Kościoła Euzebiusza z Cezarei, niezbędne wydaje się zbadanie jego poglądów na temat hierarchii czy precedencji najważniejszych biskupów. Euzebiusz przywiązywał dużą wagę do apostolskiego pochodzenia poszczególnych stolic biskupich. Przypominał o nim wielokrotnie w swojej Historii Kościoła. Jednym z zasadniczych celów, jakie sobie stawiał, było przedstawienie losów spuścizny pozostawionej przez Apostołów, z uwzględnieniem ich najwybitniejszych następców, o czym informował już na wstępie swego dzieła ${ }^{5}$. Biskup Cezarei skrupulatnie ustalał kolejność poszczególnych biskupów. Starał się przedstawić ciagłość sukcesji apostolskiej od narodzenia Chrystusa do zburzenia domów modlitwy w czasie prześladowań chrześcijan w 305 roku$^{6}$. Czy Euzebiusz miał świadomość uprzywilejowania Piotra w gronie Apostołów i czy jego poglądy na ten temat rzutowały na głoszoną przezeń precedencję wśród biskupów?

Wedle Euzebiusza, co godne podkreślenia, Apostołowie nie byli nigdzie pierwszymi biskupami, lecz działali na rzecz Kościoła powszechnego ${ }^{7}$. Piotr

${ }^{3}$ Concilium Nicaenum I (325) can. 6, tłum. T. Wnętrzak, w: Dokumenty Soborów Powszechnych (= DSP), t. 1: 325-787, układ i oprac. A. Baron - H. Pietras, ŹMT 24, Kraków 2002, 32 (tekst grec-

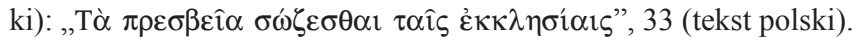

${ }^{4}$ Por. F. Dvornik, Bizancjum a prymat Rzymu, tłum. M. Radożycka, Warszawa 1985, 32.

${ }^{5}$ Por. Eusebius Caesariensis, HE I 1, 1, SCh 31, 3, tłum. A. Lisiecki: Euzebiusz z Cezarei, Historia Kościelna, POK 3, Poznań 1924, 4.

${ }^{6}$ Por. tamże VII 32, 32, SCh 41, 230-231, POK 3, 358.

${ }^{7}$ Warto w tym miejscu przypomnieć, że w Rzymie od końca III wieku uważano Apostoła Piotra 
natomiast wyróżniał się spośród pozostałych Apostołów swą cnotą. Historyk widział w nim swego rodzaju ich rzecznika. Wedle biskupa Cezarei Chrystus po zmartwychwstaniu okazać miał szczególne względy nie tylko Piotrowi, ale także Jakubom, Starszemu i Sprawiedliwemu, oraz Janowi ${ }^{8}$.

Euzebiusz miał pełną świadomość łączenia rzymskiej stolicy biskupiej z Apostołem Piotrem i równie świadomie unikał eksponowania tekstów biblijnych, z których mogłaby wynikać jakaś szczególna rola wyznaczona przez Chrystusa Piotrowi, a zatem w konsekwencji uprzywilejowanie Piotra wśród Apostołów ${ }^{9}$. Historyk obawiał się, jak można przypuszczać, wyprowadzania z pozycji Piotra pośród uczniów Chrystusa prymatu biskupa Rzymu w Kościele ${ }^{10}$. Konsekwentnie pominął też milczeniem wywody Ignacego z Antiochii (ok. 30-107) ${ }^{11}$ czy Ireneusza z Lyonu (ok. 140-202) ${ }^{12}$, wskazujące na ważną rolę odgrywaną przez Kościół rzymski w świecie chrześcijańskim ${ }^{13}$.

W relacji Euzebiusza Apostołowie ewangelizowali i zakładali Kościoły w wielu miastach Imperium Romanum. Piotr związany był przez swą działalność nie tylko z Rzymem, ale też z Jerozolimą, Cezareą Palestyńską, Antiochią, Koryntem, a także z bliżej nieokreślonymi miejscowościami w Poncie, Galacji, Bitynii, Kapadocji i Azji, oraz pośrednio z Aleksandrią i Egiptem ${ }^{14}$. Rzym o tyle tylko został wyróżniony, że tu Piotr dokonał swego żywota, i w mieście tym spoczęły doczesne jego szczątki ${ }^{15}$.

za pierwszego biskupa miasta, por. Ch. Piétri, Roma Christiana. Recherches sur l'Église de Rome, son organisation, sa politique, son idéologie de Miltiade à Sixte III (311-440), Rome 1976, 357-389.

${ }^{8}$ Por. Eusebius Caesariensis, HE II 1, 3, SCh 31, 49, POK 3, 51; zob. S. Bralewski, Obraz papiestwa w historiografii kościelnej wczesnego Bizancjum, Byzantina Lodziensia 10, Łódź 2006, 25-29.

${ }^{9}$ Por. Bralewski, Obraz papiestwa, s. 25-37.

${ }^{10} \mathrm{O}$ obawach Euzebiusza świadczyć może przemilczenie w jego Historii Kościoła interwencji podjętej w obronie ortodoksji przez papieża Dionizego Rzymskiego (259-268) na prośbę duchownych zaniepokojonych nauczaniem patriarchy Aleksandrii, Dionizego (248-264), por. Bralewski, Obraz papiestwa, s. 85-88. Jak starał się wykazać R. Minnerath (La position de l'Églises de Rome aux trois premiers siècles, w: Il primato del vescovo di Roma nel primo millennio. Ricerche e testimonianze, Atti del Symposium Storico-Teologico (Roma, 9-13 ottobre 1989), ed. M. Maccarrone, Città del Vaticano 1991, 148) w pierwotnym Kościele „les prérogatives de Pierre ne sont pas mortes avec lui, mais qu'elles lui ont survécu dans l'image que la deuxième génération chrétienne se faisait de lui, comme signe actuel de l'unité des Églises".

${ }^{11}$ Por. Ignatius Antiochenus, Epistula ad Romanos. Prologus, SCh 10, 107, tłum. A. Świderkówna, BOK 10, Kraków 1998, 128.

${ }^{12}$ Por. Irenaeus Lugdunensis, Adversus haereses III 3, SCh 34, 104, 1-3.

${ }^{13}$ Por. Bralewski, Obraz papiestwa, s. 38-39.

${ }^{14}$ Por. Eusebius Caesariensis, HE III 1, 2, SCh 31, 97, POK 3, 91-92; tamże III 4, 2, SCh 31, 100, POK 3, 94. W innym swoim dziele ( $O$ objawieniu Boga), Euzebiusz, wymieniając Kościoły założone przez Piotra, wspomniał na pierwszym miejscu Cezareę Palestyńską, a dopiero potem Antiochię, Rzym, a nawet Aleksandrię, zob. Eusebius Caesariensis, Theophania IV 6, GCS 11/2, 173, 32-34.

${ }^{15}$ Por. Eusebius Caesariensis, HE II 25, 5, SCh 31, 92, POK 3, 88. 
Euzebiusz, co jakiś czas, zwykle odnotowując zmianę panującego władcy lub konkretny rok jego panowania, dokonywał przeglądu kościelnych kadr' ${ }^{16}$. Nie czynił tego jednak w sposób systematyczny. Nie ma w jego dziele oczekiwanego porządku w podawanych przezeń zestawieniach zwierzchników najważniejszych stolic biskupich. Słabość owa wynikała najpewniej z braku stosownych źródeł bądź też luk w tych, które były dlań dostępne. Najczęściej pojawiały się w jego zestawieniach cztery biskupstwa: Rzym, Aleksandria, Antiochia i Jerozolima. Ponadto skonstatować trzeba, że sukcesja Piotrowa rzymskich biskupów stanowiła ramy, wokół których Euzebiusz przedstawił dzieje Kościoła w księgach IV-VII swej Historii. Sukcesja w Aleksandrii odegrała podobną rolę, obok rzymskiej, w księdze IV, podczas gdy biskupi Antiochii $\mathrm{w}$ takiej roli występowali rzadko, a biskupi Jerozolimy nigdy ${ }^{17}$. Można by na tej podstawie pokusić się o zrekonstruowanie hierarchii biskupów w dziele Euzebiusza. Zwraca jednak uwagę fakt, że w podanych przezeń zestawieniach wspomniani biskupi występują w różnej kolejności. Trudno zatem na tej podstawie wyciagać jakieś wnioski co do hierarchizowania ich przez autora. Można natomiast stwierdzić, że prawie zawsze biskupi Rzymu byli odnotowywani przez Euzebiusza na pierwszym miejscu ${ }^{18}$.

Eksponowanie w ten sposób Rzymu jest o tyle zaskakujące, że Euzebiusz daleki był od chęci promowania papiestwa. Niewątpliwie więc dała tu o sobie znać zasada akomodacji. Rzym jako stolica Imperium Romanum był w centrum zainteresowania wielu pisarzy, także Euzebiusza. Nie tylko jednak polityczno-cywilizacyjne znaczenie miast wycisnęło swe piętno na listach biskupów spisywanych przez Euzebiusza. Zamieszczanie w nich Jerozolimy świadczy o tym najdobitniej. Nie należała ona przecież do czołowych ośrodków miejskich Imperium Romanum, a po zburzeniu jej w roku 70, została odbudowana dopiero za panowania Hadriana (117-138) jako miasto hellenistyczne i nazwana ku czci tegoż cesarza oraz Jowisza Kapitolińskiego Colonia Aelia Capitolina ${ }^{19}$. Jej znaczenie jako ośrodka miejskiego i administracyjnego było niewielkie skoro Ammian Marcelin (ok. 330-395), opisując w Dziejach rzymskich wschodnie prowincje Cesarstwa, nie wymienił jej wśród miast

${ }^{16}$ Por. G.F. Chesnut, The First Christian Histories: Eusebius, Socrates, Sozomen, Theodoret, and Evagrius, Paris 1978, 99-102; F. Winkelmann, Historiography in the Age of Constantine, w: Greek and Roman Historiography in Late Antiquity: Fourth to Sixth Century A.D., ed. G. Marasco, Leiden 2003, 27.

${ }^{17}$ Por. V. Twomey, Apostolikos Thronos. The Primacy of Rome as reflected in the Church History of Eusebius and the historico-apologetic writings of Saint Athanasius the Great, Münster 1982, 135-136.

${ }^{18}$ Por. Bralewski, Obraz papiestwa, s. 41-43.

${ }^{19}$ Por. Eusebius Caesariensis, HE IV 6, 4, SCh 31, 166, POK 3, 150; zob. Dio Cassius, Historia Romana 69, 12; D. Golan, Hadrian's Decision to supplant Jerusalem by Aelia Capitolina, „Historia” 35 (1986) 226-239. 
Palestyny, choć znalazło się tam miejsce nie tylko dla Cezarei, lecz również dla Askalonu, Eleutheropolis, Gazy i Neapolis ${ }^{20}$.

Według Historii Kościoła Euzebiusza w pierwszych dziesiątkach lat dziejów Kościoła to nie rzymska wspólnota ze swoim biskupem zajmowała w nim naczelną pozycję, ale Kościół w Jerozolimie. Ten ostatni stracił jednak znaczenie po zniszczeniu miasta po powstaniu Bar-Kochby (132-135), co wyraźnie starał się Euzebiusz zaznaczyć. Jak się wydaje, od urodzin będąc związanym z Cezareą, a od 313 r. pełniąc urząd jej biskupa, historyk nie był w żaden sposób zainteresowany, aby bronić prestiżu biskupa Jerozolimy, który podlegał metropolitalnej władzy Cezarei ${ }^{21}$. Widać to wyraźnie w zestawieniach zwierzchników kościelnych, kiedy trzykrotnie Euzebiusz wymienił biskupów Cezarei Palestyńskiej przed jerozolimskimi22 ${ }^{2}$. Myślę, że nie można wykluczyć, iż podkreślanie przezeń wysokiej rangi Kościoła w Jerozolimie w początkach chrześcijaństwa miało stanowić przeciwwagę dla ideologii prymatu rzymskiego wyprowadzanego z czasów apostolskich ${ }^{23}$.

Mimo to Euzebiusz wymieniał biskupa Rzymu na pierwszym miejscu, przyznając mu pierwszeństwo. Miało ono jednak charakter honorowy, gdyż w jego przekonaniu nie szła za nim realna zwierzchność, tzn. pierwszeństwo to nie przekładało się na żadną formę jurysdykcji, a rozpatrywać je można jedynie na płaszczyźnie precedencji. Tak więc, jak się wydaje, Euzebiusz w tworzonych przez siebie zestawieniach biskupów kierował się zasadą akomodacji, robiąc wyjątek dla Jerozolimy, ale i w tym wypadku zasada ta zwyciężała kiedy Jerozolimę poprzedzała Cezarea Palestyńska.

${ }^{20}$ Por. Ammianus Marcellinus, Rerum gestarum XIV 8, 11, tłum. I. Lewandowski: Dzieje rzymskie, t. 1, Warszawa 2002, 92.

${ }^{21}$ Por. J. Pollok, Narodziny koncepcji „Ziemi Świętej”. Palestyna w teologicznej refleksji Euzebiusza z Cezarei i Cyryla Jerozolimskiego, w: Chrześcijaństwo u schyłku starożytności. Studia źródłoznawcze, red. T. Derda - E. Wipszycka, t. 1, Warszawa 1997, 103-105.

${ }^{22}$ Por. Eusebius Caesariensis, HE V 22, SCh 41, 65, POK 3, 237; VII 14, SCh 41, 188, POK 3, 325; VII 32, 24, SCh 41, 228, POK 3, 357; VII 32, 29, SCh 41, 230, POK 3, 358. J. Pollok (Narodziny, s. 103) konstatuje, że w Historii Kościoła Euzebiusza nie da się zauważyć objawów napięcia między Cezareą a Jerozolimą, co wydaje się kłaść na karb powstania dzieła na długo przed 313 rokiem, a więc na czas, zanim historyk został biskupem Cezarei. Jeśli natomiast wziąć pod uwage argumenty R.W. Burgessa (The date and editions of Eusebius'Chronici Canones and Historia Ecclesiastica, JTS 48:1997, 471-504) i przesunąc pierwsze wydanie Historii na lata 313/314, trzeba znaleźć inne uzasadnienie dla wspomnianej postawy Euzebiusza, tym bardziej, że nie można jej sprowadzać tylko do braku przejawów rywalizacji między Kościołami rzeczonych miast, skoro wyraźnie pierwszoplanową rolę w świecie chrześcijańskim przypisuje on wspólnocie jerozolimskiej.

${ }^{23}$ Por. Bralewski, Obraz papiestwa, s. 44-49. Zdaniem R. Minnerath (La position de l'Églises de Rome, s. 146): „L'Église de Rome avait conscience d'être l'héritière de la tradition hiérosolomitaine de Jacques et de celle de Pierre, «Apôtre de Jésus-Christ» (1P 1,1), réconcilié avec un Paul plus modéré. Ayant recueilli cet héritage, l'Église de Rome était devenue comme la nouvelle ÉgliseMère, dans le rôle jadis dévolu à Jérusalem". Euzebiusz nie wyrażał jednak podobnego przekonania. 
2. Filostorgiusz (ok. 368-433). Najwcześniejsze z Historii kościelnych $\mathrm{V}$ wieku jest dzieło Filostorgiusza. Niestety znamy je tylko we fragmentach i to $\mathrm{z}$ drugiej ręki. Bardzo więc trudno interpretować jego przekaz na temat pierwszeństwa przysługującego poszczególnym biskupom, tym bardziej, że był on arianinem, wyznawcą doktryny anomejskiej. Historyk miał na pewno świadomość sukcesji apostolskiej. Pisał bowiem, że Eulaliusz (331-333) był 23. biskupem antiocheńskim po Apostołach ${ }^{24}$. W innym miejscu zaś wskazywał, że Maksym III (333/334-351) był 40. biskupem Jerozolimy, Atanazy (295-373) zaś 18. biskupem Aleksandrii. Po nich wymienił dopiero biskupa Antiochii, którego imię w tekście się nie zachowało ${ }^{25}$. Fragment ów jest niepełny. Czy zatem na jego podstawie można sugerować, że Filostorgiusz dawał pierwszeństwo biskupowi Jerozolimy przed biskupem Aleksandrii i Antiochii? Trudno powiedzieć.

3. Sokrates Scholastyk (ok. 380-450). Kolejny historyk Kościoła z V wie$\mathrm{ku}$, Sokrates miał świadomość apostolskiego pochodzenia stolic biskupich. Znał przecież dzieło Euzebiusza z Cezarei, a i sam wspomniał w odniesieniu do Ignacego z Antiochii, że był on jej trzecim biskupem po Apostole Piotrze ${ }^{26}$. Jak się jednak wydaje, Piotrowe pochodzenie biskupstwa nie przekładało się dla Sokratesa w żaden sposób na praktykę życia kościelnego, a co za tym idzie nie dawało żadnego tytułu do pierwszeństwa w Kościele. Nie wynosił przecież biskupów Antiochii nad innych hierarchów z władzą ponadmetropolitalną.

Zwracając uwagę na różnice $w$ terminie obchodzenia święta Paschy, Sokrates podkreślał, że biskupi na Zachodzie opowiadali się za kultywowaniem w tej kwestii tradycji pochodzącej od Apostołów Piotra i Pawła ${ }^{27}$, tak jak kwartodecymanie odwoływali się w tej materii do Apostoła Jana. Wywodził, że żadna ze stron nie była jednak w stanie przedstawić rzeczowych dowodów opartych na Biblii. Mimo więc, że Sokrates wydawał się dostrzegać ciagłość tradycji zachowywanej od czasów apostolskich w Kościołach, to wedle niego ani Zbawiciel, ani Apostołowie nie zostawili na ten temat żadnych rozporządzeń. Stawiali sobie bowiem cele o wiele bardziej wzniosłe, jak zaprowadzenie sprawiedliwego życia i bogobojności. Na tym tle regulowanie celebracji świąt wydawało się historykowi kwestią mało znaczącą, o której decydowały lokalne zwyczaje, tak jak w wielu innych sprawach. W przekonaniu zatem Sokratesa tradycja apostolska dotyczyła jedynie rzeczy zasadniczych. Na tej podstawie można domniemywać, że historyk wykluczał jej wpływ na kwestię pierwszeństwa w Kościele.

\footnotetext{
${ }^{24}$ Por. Philostorgius, HE III 15b, GCS 21, 45, 33-34.

${ }^{25}$ Por. tamże, GCS 21, 206, 26-27 (= Anhang VII: Fragmente eines Arianischen historiographen, 7 und 8a).

${ }^{26}$ Por. Socrates, HE VI 8, 11, 36-38, SCh 505, 298, tłum. S. Kazikowski: Sokrates Scholastyk, Historia Kościoła, Warszawa 1986², 466.

${ }^{27}$ Tamże V 22, 28, 105-107, SCh 505, 224, thum. Kazikowski, s. 429.
} 
Widać to także w przekazie Sokratesa w odniesieniu do Konstantynopola. Historyk wspominał jedynie, że Konstantyn, rozbudowując Byzantion, uczynił z niego miasto równe Rzymowi, co wydaje się dotyczyć głównie jego wyglądu i znaczenia politycznego ${ }^{28}$. W relacji Sokratesa cesarz specjalną ustawą zapewnić miał Konstantynopolowi tytuł Drugiego Rzymu ${ }^{29}$. Historyk nie rozwodził się też nad kanonem Soboru Konstantynopolitańskiego (381), nadającym biskupowi wschodniej stolicy imperium godność drugiego biskupa Cesarstwa, zaraz po biskupie Rzymu, a zacytował jedynie oficjalne uzasadnienie stwierdzające, że Konstantynopol jest Nowym Rzymem ${ }^{30}$.

W tym kontekście ciekawie wyglądają zestawienia najważniejszych biskupów podane przez Sokratesa. Pierwsze z nich dotyczy Soboru Nicejskiego (325). Historyk przedstawił początek listy biskupów, którzy kolejno wyrażali akceptację dla ułożonego w czasie obrad credo. Z tekstu wynika, że wykaz ów zaczerpnął Sokrates z Liber synodicus Atanazego, biskupa Aleksandrii, który był osobiście obecny w Nicei. Można było zatem spodziewać się, że sporządził ową listę na podstawie protokołów obrad, będących w dyspozycji Kościoła w Aleksandrii. Na pierwszym miejscu wymieniony został tam Hozjusz (ok. 256-359), biskup Kordoby, na drugim przedstawiciele biskupa Rzymu, prezbiterzy Wiktor i Wincenty, na trzecim Aleksander I (313-328), biskup Aleksandrii, na czwartym Eustacjusz (ok. 324-332), biskup Antiochii i w końcu na piątym biskup Jerozolimy Makary I (314-333) ${ }^{31}$. O ile wspo-

${ }^{28}$ Por. Socrates, HE I 16, 1-4, 1-25, SCh 477, 172-174, tłum. Kazikowski, s. 108-109. Na polityczny wymiar, jaki miał akt założenia nowej stolicy wskazywał M. Salamon (Nowy Rzym chrześcijański w oczach Bizantyńczyków, w: Prawosławie, red. J. Drabina, Kraków 1996 = „Studia Religiologica” 19:1996,12). Konstantynopol, stawszy się nową stolicą cesarstwa, nie mógł nadal podlegać Heraklei, metropolii diecezji Tracji.

${ }^{29}$ Por. Socrates, HE I 16, 1, 7-12, SCh 477, 172, tłum. Kazikowski, s. 108. Według Sokratesa prawo to miało zostać wyryte na kolumnie wystawionej na placu zwanym Strategion. W innych źródłach nie ma żadnej wzmianki na temat podobnego aktu prawnego, jeśli nie liczyć tych zawartych w dziele Hezychiusza Illustriosa (Patria Constantinoupoleos 39, ed. Th. Preger, Scriptores Originum Constantinopolitanarum [= SOC] fasc. 1, Lipsiae 1901, s. 17, 3-6) i Kronice Wielkanocnej (Chronicon Paschale, ed. L. Dindorfius, Corpus Scriptorum Historiae Byzantinae 6/2, Bonnae 1882, s. 529, 17-18 = PG 92, 709C-712A), które G. Dagron (Naissance d'une capitale: Constantinople et ses institutions de 330 à 451, Bibliothèque Byzantine. Études 7, Paris 1984, 45) uważa za przejęte z Historii Kościoła Sokratesa i jest w związku z tym przekonany o jego pomyłce w tej sprawie. Przeciwnego zdania jest M. Salamon (Rozwój idei, s. 30-31), w przekonaniu którego także teksty Sozomena (HE II 3, 5, SCh 306, 238, tłum. S. Kazikowski: Hermiasz Sozomen, Historia Kościoła, Warszawa 1989, 85) i Filostorgiusza (HE II 9, GCS 21, 20, 6-22, 5) oparte są na inskrypcji ze Strategionu (tamże, s. 35).

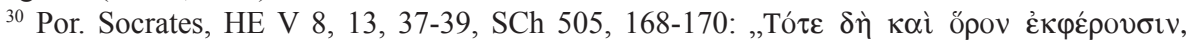

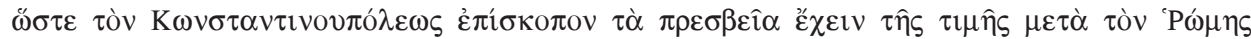

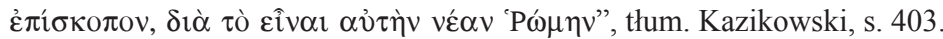

${ }^{31}$ Por. tamże I 13, 12, 53-87, SCh 477, 154-156, tłum. Kazikowski, s. 105. Zachowano tutaj kolejność biskupów występującą w wiekszości manuskryptów Historii Kościoła Sokratesa. W wydaniu GCS NF 1, 46-51 (a za nim SCh 477) Günther Christian Hansen zrekonstruował listę uczest- 
mnianą listę i zarazem kolejność wymienionych tam biskupów zaczerpnął Sokrates z dzieła Atanazego, to sam zadecydował, ilu znajdujących się na niej duchownych zamieści w swojej relacji. Widać skupił się na tych, których uznał za najważniejszych.

Pierwsze miejsce przypisane tu Hozjuszowi związane jest z rolą jaką odgrywał ów biskup przy boku cesarza Konstantyna I (306-337), będąc w tym czasie jego głównym doradcą w sprawach kościelnych ${ }^{32}$. Jednak już drugie, na którym figurowali legaci biskupa rzymskiego, łączyć należy z pozycją zajmowaną przez biskupa stolicy w Kościele powszechnym. Jego reprezentanci wszak sami z siebie nie posiadali wystarczającego autorytetu, aby zajmować tak eksponowane miejsce, tym bardziej, że nie byli biskupami.

O ile z pozycją biskupów Rzymu, Aleksandrii i Antiochii można wiązać znaczenie polityczne miast, w których rozwijały się ich Kościoły, o tyle wymienienie na piątym miejscu biskupa Jerozolimy należy przypisać jedynie względom religijnym i historycznemu znaczeniu miasta - miejsca w przekonaniu chrześcijan uświęconego życiem, śmiercią i zmartwychwstaniem Chrystusa.

Zwraca uwagę fakt, że przed biskupem Jerozolimy nie pojawiło się w tym zestawieniu imię Euzebiusza, biskupa Cezarei Palestyńskiej, który, jak wiemy, wziął udział w obradach i zaakceptował przyjęte tam credo ${ }^{33}$. Biskup Jerozolimy podlegał przecież władzy kościelnej biskupa Cezarei i z tego powodu winien być wymieniany po nim. Dawał temu wyraz w swej Historii Kościoła sam Euzebiusz. Trzeba to thumaczyć poglądami Atanazego, z którego dzieła Sokrates, jak sam wyznał, zaczerpnął fragment wspomnianej listy biskupów. Ten zaś widział w Euzebiuszu heretyka-arianina i wroga przyjętej w Nicei formuły wiary ${ }^{34}$. Wydaje się, że z tego samego powodu biskup Aleksandrii nie przyznał czołowego miejsca Euzebiuszowi z Nikomedii $(† 341)$, kościelnemu zwierzchnikowi miasta, w którym odbywały się obrady, chociaż ten z tej racji, jak można przypuszczać, odgrywał w nich niepoślednią rolę.

W pozostałych zestawieniach najważniejszych biskupów sporządzonych przez Sokratesa na pierwszym miejscu znajduje się zwierzchnik Kościoła rzymskiego ${ }^{35}$. Drugim miejscem Sokrates obdarzał dość konsekwentnie bisku-

ników soboru na podstawie manuskryptu Marcianus Venetus gr. 344 oraz innych źródeł, zob. SCh 477, 152-153, przyp. 2.

${ }^{32}$ Por. V.C. de Clercq, Ossius of Cordova. A Contribution to the History of the Constantinian period, Studies in Christian Antiquity 13, Washington 1954.

${ }^{33}$ Por. G.C. Stead, Eusebius and the Council of Nicaea, JTS 24 (1973) 85-100; Th.D. Barnes, Constantine and Eusebius, London 1981, 216.

${ }^{34}$ Por. Ch. Kannengiesser, Athanasius of Alexandria. Three orations against the Arians: a reappraisal, StPatr 17 (1982) vol. 3, 981-995.

${ }^{35}$ Por. Socrates, HE IV 1, 14, 38-39, SCh 505, 26, thum. Kazikowski, s. 330; V 3, 1, 1-2, SCh 505, 154, tłum. Kazikowski, s. 396; VI 1, 2, 5-6, SCh 505, 258, tłum. Kazikowski, s. 447. Nie został on uwzględniony dwa razy, kiedy historyk zajmował się uczestnikami soborów w Konstantynopolu z roku 381, zob. tamże V 8, 3-5, 6-14, SCh 505, 166, thum. Kazikowski, s. 401) i w Efezie z roku 
pa Aleksandrii ${ }^{36}$. Na trzecim miejscu na ogół umieszczał biskupów Jerozolimy przed biskupami Antiochii ${ }^{37}$.

Podobną regularność możnazauważyć takżew przypadkuKonstantynopola. Sokrates wymieniał jego biskupa konsekwentnie na ostatnim miejscu spośród pięciu najważniejszych biskupstw. Czynił to wbrew 3. kanonowi Soboru Konstantynopolitańskiego I (381), o którym sam informował w swoim dziele. W jego relacji obecni na obradach biskupi „ogłosili kanon, że biskup Konstantynopola ma przywilej godności zaraz po biskupie Rzymu, ponieważ Konstantynopol jest nowym Rzymem"38.

Przyjęta zatem przez Sokratesa kolejność biskupstw byłaby następująca: Rzym, Aleksandria, Jerozolima, Antiochia, Konstantynopol. Ostatnie podane przez Sokratesa zestawienie biskupów, które zachowuje taką właśnie kolejność, umieścił on relacjonując wydarzenia, mające miejsce po śmierci cesarza Teodozjusza I (379-395) $)^{39}$, a okres ten nazwał współczesną sobie epoką ${ }^{40}$. O ile umieszczenie na pierwszym miejscu Rzymu, a na drugim Aleksandrii, mogłoby świadczyć o kierowaniu się przezeń zasadą akomodacji, to już umieszczenie Jerozolimy przed Antiochią kłóci się z nią wyraźnie, a jeszcze bardziej sprzeczne $\mathrm{z}$ nią wydaje się ostatnie miejsce przewidziane dla Konstantynopola. Zaskakuje ono tym bardziej, że sam Sokrates związany był przecież ze środowiskiem konstantynopolitańskim. Znał też 3. kanon Soboru Konstantynopolitańskiego (381), a w dodatku pisał wbrew prawdzie o istnieniu kanonu zakazującego wyznaczania kogokolwiek na urząd biskupi wbrew opi-

431, por. tamże VII 34, 6-9, 18-32, SCh 505, 122-124, thum. Kazikowski, s. 545. Na pierwszym z nich nie było ani biskupa Rzymu, ani jego przedstawicieli. Natomiast na drugim jego legaci przybyli z dużym opóźnieniem i nie odegrali aktywnej roli.

${ }^{36} \mathrm{Z}$ jednym wyjątkiem, kiedy wymieniając rządzących poszczególnymi Kościołami za panowania cesarzy Gracjana (375-383) i Teodozjusza I, na drugim miejscu wymienił biskupa Jerozolimy, por. tamże V 3, 1, 2-3, SCh 505, 154, tłum. Kazikowski, s. 396. Trzeba jednak zaznaczyć, że zwierzchnicy Kościołów w Rzymie i w Jerozolimie byli jedynymi spośród wspomnianych, których Sokrates uważał za ortodoksów i którzy niepodzielnie zarządzać mieli swoimi Kościołami. Pozostali uwzględnieni przezeń hierarchowie stali na czele wspólnot podzielonych między ortodoksów i heretyków, bądź sami byli heretykami. Wskazana prawidłowość nie tłumaczy jednak całkowicie kolejności zastosowanej przez Sokratesa, gdyż w innym fragmencie swej Historii Kościoła, mimo rozłamów targających Kościołami Aleksandrii i Antiochii, wymienił biskupa Jerozolimy dopiero na czwartym miejscu, a więc po biskupach rzeczonych wspólnot chrześcijańskich, zob. tamże IV 1, 14-16, 38-48, SCh 505, 26, tłum. Kazikowski, s. 330.

${ }^{37}$ Por. tamże V 3, 1, 1-4, SCh 505, 154, thum. Kazikowski, s. 396; V 8, 3-4, 6-9, SCh 505, 166, tłum. Kazikowski, s. 401; VI 1, 2, 5-10, SCh 505, 258, thum. Kazikowski, s. 447; VII 34, 3, 6-10, SCh 506, 122, tłum. Kazikowski, s. 545. Poza jednym wzmiankowanym już wyjątkiem czynił to konsekwentnie (nie liczę tu listy podanej przy okazji zatwierdzenia credo nicejskiego, gdyż była cytowana za Atanazym).

${ }^{38}$ Tamże V 8, 13, 37-39, SCh 505, 168-170, tłum. Kazikowski, s. 403.

${ }^{39}$ Por. tamże VI 1, 1-2, 1-10, SCh 505, 258, thum. Kazikowski, s. 447.

${ }^{40}$ Por. tamże VI (Prologus) 6, 19, SCh 505, 256, thum. Kazikowski, s. 445. 
nii biskupa Konstantynopola ${ }^{41}$. Niewykluczone, że Sokrates myślał tu o edykcie Teodozjusza II (408-450) z roku 421, według którego nie można było ordynować biskupów w Illiricum bez zgody i wiedzy biskupa Konstantynopola, cieszącego się takimi samymi prerogatywami, jak biskup Starego Rzymu ${ }^{42}$. W każdym razie Sokrates, pisząc o nieistniejącym kanonie, sam zwiększał znaczenie biskupa Konstantynopola w Kościele, a jednocześnie, wymieniając go jako ostatniego z grona pięciu najważniejszych biskupów, umniejszał je. Widać zatem w postępowaniu Sokratesa jaskrawą sprzeczność.

Być może wynikała ona $\mathrm{z}$ zaangażowania historyka w walki frakcyjne, mające miejsce $\mathrm{w}$ łonie samego duchowieństwa Konstantynopola. Sokrates wytrwale popierał Proklosa (434-446) w jego staraniach o urząd biskupa stolicy, a krytykował jego przeciwników z Filipem z Side († po 431) na czele. Miał także krytyczny stosunek do niektórych biskupów Konstantynopola, a konkretnie do Jana Chryzostoma (398-404), czy Nestoriusza (428-431) ${ }^{43}$. Prawdopodobnie jednak jego ocena działalności zwierzchników Kościoła stolicy wschodniej części cesarstwa nie miała wpływu na wspomnianą kolejność. Wychwalał przecież innych biskupów Konstantynopola: Attyka (406-425), Sisinniosa I (426-427), a przede wszystkim współczesnego mu Proklosa ${ }^{44}$. Krytykował zaś także biskupów Rzymu, głównie Innocentego I (401-417) ${ }^{45}$, czy biskupów Aleksandrii: Teofila I (384-412) i Cyryla (412-444) ${ }^{46}$, a komentując perturbacje mające miejsce w Kościele, pisał nawet, iż ,zło wzięło początek z Egiptu" ${ }^{47}$. Krytycyzm ów nie miał jednak żadnego przełożenia na miejsce, jakie Sokrates przyznawał biskupom Rzymu i Aleksandrii w swych zestawieniach zwierzchników kościelnych.

${ }^{41}$ Por. tamże VII 28, 2, 5-9, SCh 506, 106, thum. Kazikowski, s. 536.

${ }^{42}$ Por. Codex Theodosianus XVI 2, 45, SCh 497, éd. Th. Mommsen, Paris 2005, 212. Według błędnej interpretacji Edmunda Przekopa (Wschodnie patriarchaty starożytne (IV-X w), Warszawa 1984, 31) edykt cesarski z 421 r. regulował sytuację w trzech diecezjach: Azji, Tracji i Pontu. Nic ponoć nie mogło się tam dokonać bez uprzedniej wiedzy biskupa Konstantynopola. W Kodeksie Teodozjusza takiego edyktu jednak nie ma.

${ }^{43}$ Por. P. Van Nuffelen, Un héritage de paix et de piété. Étude sur les histoires ecclésiastiques de Socrate et de Sozomène, Leuven 2004, 20-35; S. Bralewski, Rozbieżności w ocenie Jana Chryzostoma w relacjach Sokratesa i Hermiasza Sozomena, w: Cesarstwo Bizantyńskie: dzieje, religia, kultura. Studia ofiarowane Profesorowi Waldemarowi Ceranowi przez uczniów na 70-lecie Jego urodzin, red. P. Krupczyński - M. Leszka, Łask 2006, 9-24.

${ }^{44}$ Por. Socrates, HE VII 3, 11-12, 31-38, SCh 506, 26, thum. Kazikowski, s. 500; VII 4, 1-3, 1-11, SCh 506, 26-28, thum. Kazikowski, s. 500; VII 26, 1-4, 1-16, SCh 506, 100-102, thum. S. Kazikowski, s. 534; VII 41, 1-7, 1-20, SCh 506, 142-144, tłum. Kazikowski, s. 556.

${ }^{45}$ Por. tamże, VII 9-11, SCh 506, 40-46, thum. Kazikowski, s. 506-509.

${ }^{46}$ Sokrates (VII 7, 1-5, 1-17, SCh 506, 34-36, thum. Kazikowski, s. 503-504) konstatował z nagana, iż od czasu intronizacji biskupa Cyryla: ,władza biskupa Aleksandrii niezależnie od spraw episkopatu zaczęła obejmować sprawy publiczne"; por. tamże VII 7, 4, 11-13, SCh 506, 34-36, thum. Kazikowski, s. 504.

${ }^{47}$ Tamże, VI 6, 42, 135-136, SCh 505, 286, thum. Kazikowski, s. 460. 
Przyznanie pierwszeństwa biskupowi Jerozolimy przed biskupem Antiochii mogło wynikać z poparcia dążeń biskupa Jerozolimy do uniezależnienia się nie tylko od metropolitalnej zwierzchności kościelnej biskupa Cezarei Palestyńskiej, ale także od zwierzchności ponadmetropolitalnej biskupa Antiochii, do czego dążył Juwenal (422-458), ówczesny zwierzchnik Kościoła jerozolimskiego ${ }^{48}$. Pewne kroki w tym kierunku podejmował już wcześniej Cyryl Jerozolimski (351-386) ${ }^{49}$. Sozomen (ok. 400-450) wspominał, że poróżnił się on z Akacjuszem (†366/367), biskupem Cezarei Palestyńskiej „W przedmiocie uprawnień metropolitalnych, uważając się za zwierzchnika siedziby apostolskiej" 50 . Juwenal odwoływał się w sprawie godności swego urzędu do Soboru Efeskiego (431), a potem Sobór Chalcedoński (451) rozpatrywał w tej kwestii jego spór z Maksymem II (449-455), biskupem Antiochii $^{51}$. W Chalcedonie Jerozolimę wyniesiono jako miasto zmartwychwstania Chrystusa ${ }^{52}$. Prawdopodobnie aspiracje biskupa jerozolimskiego popierała cesarzowa Eudokia (ok. 400-460), o której wyprawie do Jerozolimy wspominał Sokrates ${ }^{53}$. O samym jednak Juwenalu historyk wypowiadał się mało przychylnie. Stwierdził bowiem, że ten wraz z Cyrylem, biskupem Aleksandrii, ,chcąc wywrzeć zemstę na Janie [biskupie Antiochii], zdetronizowali go" 54 .

Szukając przyczyn, dla których Sokrates zastosował wspomnianą kolejność biskupów, nie można pominąć wpływów zewnętrznych. Wydaje się, że mógł ją przejąć z Historii Kościoła Rufina z Akwilei (ok. 345-410), na której ściśle się opierał, szczególnie przy pisaniu pierwszej wersji swego dzieła, o czym sam wspomina ${ }^{55}$. Otóż Rufin zestawił biskupów dokładnie w takiej samej kolejności, co Sokrates ${ }^{56}$. Rufin też miał powody, aby faworyzować biskupów Jerozolimy. Przez dwadzieścia lat bowiem związany był z tamtej-

${ }^{48}$ Por. E. Honigmann, Juvenal of Jerusalem, DOP 5 (1950) 209-279.

${ }^{49}$ Por. J.W. Drijvers, A Bishop and his City - Cyril of Jerusalem, StPatr 42 (2006) 113-125; E. Yarnold, Cyril of Jerusalem, London - New York 2000, 4-8; P. Van Nuffelen, The career of Cyril of Jerusalem (c. 348-87). A Reassessment, JTS NS 58 (2007) 141-145.

${ }^{50}$ Sozomenus, HE IV 25, 2, SCh 418, 332, thum. Kazikowski, s. 274.

${ }^{51}$ Por. Przekop, Wschodnie patriarchaty, s. 33-34 oraz s. 176, przyp. 49.

${ }^{52}$ Por. Concilium Chalcedonense (451), ACO II 1, 2, ed. E. Schwartz, Berolini - Lipsiae 1933, s. 121[317], 21 (V 1, 6); tamże, s. 125 [321], 31-32 (V 29); tamże, s. 130 [326], 32 (VI 1, 6); tamże, s. 141[337], 29 (VI 9, 6).

${ }_{53}$ Por. Socrates, HE VII 47, 1-3, 1-9, SCh 506, 154-156, thum. Kazikowski, s. 501-502; zob. H. Leclercq, Pèlerinage aux Lieux Saints, XV: Le pèlerinage d'Eudocie, DACL XIV 116120; C. Horn, Empress Eudocia and the Monk Peter the Iberian: Patronage, Pilgrimage, and the Love of a Foster-Mother in Fifth-Century Palestine, ByF 28 (2004) 206-213; P. Maraval, Lieux saints et pèlerinages d'Orient. Histoire et géographie des origines à la conquête arabe, préface de G. Dagron, Paris 2004², 69-70.

${ }^{54}$ Socrates, HE VII 34, 9, 31-32, SCh 506, s. 124, thum. Kazikowski, s. 547.

${ }_{55}^{55}$ Por Socrates, HE I 12.

${ }^{56}$ Por. Rufinus Aquileiensis, HE II 21, PL 21, 527B-528A. 
szym Kościołem. Rufin przybył do Jerozolimy w 377 r., gdzie od kilku już lat, prawdopodobie od 374 r., przebywała wspierająca go materialnie Melania Starsza († 410). Dzięki jej pomocy założył tam klasztor na Górze Oliwnej. Wraz z Melanią Starsza, która stworzyła w pobliżu klasztoru Rufina żeńską wspólnotę, obejmowali opieką pielgrzymów przybywających do Jerozolimy, rozszerzając akcję charytatywną także na jej mieszkańców. Wydaje się, że Rufina łączyła swego rodzaju zażyłość z biskupem Jerozolimy Janem II (386417), z którego rąk przyjął święcenia kapłańskie ok. 390 roku. Rufin więc nie bez przyczyny popierał wysokie aspiracje biskupów Jerozolimy w Kościele powszechnym. Można jednak przypuszczać, że tworząc wspomniane zestawienia biskupów, kierował się on przede wszystkim zasadą apostolskiego pochodzenia biskupstw, a Sokrates kolejność tę przejął.

4. Hermiasz Sozomen († 450). Historia Kościoła Sozomena, podobnie jak dzieło Sokratesa, prezentowała konstantynopolitański punkt widzenia. Między nimi występuje poza tym bardzo duża zależność, gdyż Sozomen właściwie poprawiał i uzupełniał dzieło Sokratesa ${ }^{57}$. Można nawet założyć, że od początku przystępował do pracy nad dziejami Kościoła z zamiarem dokonania korekty interpretacji, przedstawionej przez Sokratesa.

W przekonaniu Sozomena Piotr zajmował wyjątkową pozycję wśród Apostołów, jako ich lider. Streszczając bowiem edykt wydany przez cesarza

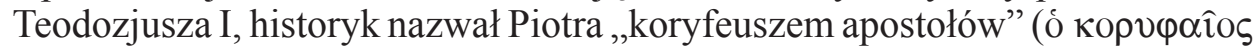
$\tau \hat{\omega} \nu$ ỏ $\pi 0 \sigma \tau o ́ \lambda \omega v)^{58}$, mimo że we wspomnianym akcie prawnym nie było podobnego określenia. Sozomen wprowadził zatem ów dodatek w pełni świadomie. Tronem Piotrowym nazywał zaś rzymską stolicę biskupią określając ją też mianem tronu apostolskiego, czym dawał dowód, iż wywodził biskupów Rzymu od Apostoła Piotra ${ }^{59}$. Podkreślając Piotrowe pochodzenie rzymskiej stolicy biskupiej, Sozomen wydaje się wskazywać na prymat biskupa Rzymu.

Przy czym, o ile pierwszy ze wskazanych tytułów rezerwował jedynie dla biskupiej siedziby w Rzymie, o tyle drugim z nich obdarzał także sto-

${ }^{57}$ Zwracano na to uwage wielokrotnie, por. Chesnut, The First Christian Histories, s. 205; G. Sabbah, Introduction, III: Sozomène et Socrate, w: Sozomène, Histoire ecclésiastique, livres I-II, SCh 306, Paris 1983, 59; F.M. Young, From Nicaea to Chalcedon: a guide to the literature and its background, London 1983, 32; Th.D. Barnes, Athanasius and Constantius: theology and politics in the Constantinian empire, Cambridge 1993, 206; T. Urbainczyk, Observations on the Differences between the Church Histories of Socrates and Sozomen, „Historia” 46 (1997) 355-356. W przekonaniu P. Janiszewskiego (Żywioły w stużbie propagandy, czyli po czyjej stronie stoi Bóg. Studium klęsk i rzadkich fenomenów przyrodniczych u historyków Kościoła w IV i V wieku, w: Chrześcijaństwo u schyłku starożytności. Studia źródłoznawcze, t. 3, red. T. Derda - E. Wipszycka, Kraków 2000, 153) Sozomen „chciał stworzyć konkurencyjne dla Sokratesa dzieło, bliższe kanonom klasycznej literatury i gustom klasycyzujących środowisk intelektualnych Konstantynopola".

${ }^{58}$ Sozomenus, HE VII 4, 6, 29, SCh 516, s. 84, thum. Kazikowski, s. 458.

${ }^{59}$ Por. tamże IV 15, 6, SCh 418, 256, thum. Kazikowski, s. 237. 
lice biskupie w Jerozolimie, Antiochii i Aleksandrii ${ }^{60}$. Podkreślić trzeba jednak, że Sozomen tronem apostolskim nie nazwał ani razu biskupstwa w Konstantynopolu. Historyk wydaje się natomiast wyprowadzać jego wysoką rangę ze związku z Rzymem, który to związek został wykreowany przez cesarza Konstantyna, działającego na polecenie samego Boga. To Bóg wybrał Byzantion na miejsce nowej stolicy, a cesarz posłuszny Jego głosowi, powiększył obszar miasta, otoczył je murami, rozbudował, zasiedlił ludnością sprowadzoną m.in. ze „Starszego Rzymu” i nie tylko nazwał od swego imienia Konstantynopolem, ale i „Nowym Rzymem”. Wysiłki władcy, aby zrównać we wszystkim nową stolicę z italskim Rzymem ${ }^{61}$, zostały uwieńczone powodzeniem, bowiem dzięki łasce Bożej rozrosła się ona do tego stopnia, że liczbą mieszkańców i bogactwem przewyższyła dawną. Bóg zaś wspierał zapał cesarza i poprzez swe objawienia potwierdzał świętość wybudowanych przezeń kościołów. Tak więc nowa stolica, zrównana w prawach ze starą, stała się współuczestniczką jej pierwszeństwa, godnością dorównując pierwszej

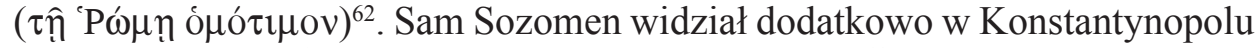
miasto Chrystusa ${ }^{63}$, nie znające pogańskich kultów ${ }^{64}$. Mimo zatem, że nie miało ono apostolskiego pochodzenia, jego pozycja dorównywała Rzymowi $\mathrm{z}$ woli nie tylko cesarza, lecz także samego Boga.

Omawiając 3. kanon Soboru Konstantynopolitańskiego I, historyk nie ograniczył się do przedstawienia jego zwięzłej treści, gdzie mowa jest o przywileju pierwszeństwa $(\pi \rho \varepsilon \sigma \beta \varepsilon i \hat{\alpha})$, jaki po biskupie Rzymu miał przysługi-

${ }^{60}$ Por. tamże I 2, 2, SCh 306, 122, thum. Kazikowski, s. 36; tamże I 17, 2, SCh 306, 194, thum. Kazikowski, s. 68.

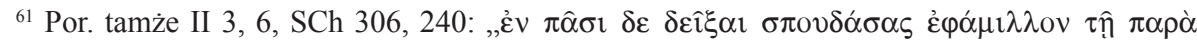

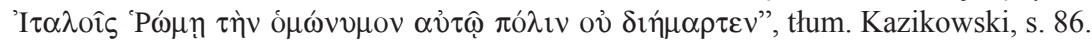

${ }^{62}$ Por. tamże II 3, 2, SCh 306, 236, tłum. Kazikowski, s. 85; zob. też tamże II 3, 1, SCh 306,

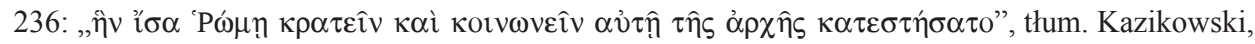
s. 85. Według F. Dvornika (Bizancjum a prymat Rzymu, s. 30-31) przeniesienie rezydencji cesarskiej na Wschód stało się silnym bodźcem dla rozwoju idei Piotrowej w Rzymie.

${ }^{63}$ Por. Sozomenus, HE II 3, 7, SCh 306, s. 240, thum. Kazikowski, s. 86-87; zob. też Eusebius Caesariensis, Vita Constantini III 48, GCS 7, 98, 1-11, tłum. T. Wnętrzak, ŹMT 44, Kraków 2007 , 193. Według G. Dagrona (Naissance d'une capitale, s. 38-39) późniejsze źródła donoszące o dedykacji miasta Chrystusowi inspirowały się przekazami Euzebiusza i Sozomena, por. Nicephorus Callistus Xanthopulus, HE VII 49, PG 145, 1325C-D; Georgius Cedrenus, Historiarum compendium, CSHB 4/1, s. 565, 1-4 (= PG 121, 613C).

${ }^{64}$ Przeczy temu pierwsza ceremonia fundacji miasta z roku 324, mająca charakter pogański, por. G. Dagron, Naissance d'une capitale, s. 29-47. 373. Por. też Zosimus, Historia nova, II 31, 1-3, thum. H. Cichocka, s. 107; Hesychius Illustris, Patria Constantinoupoleos 15-16, SOC fasc. 1, s. 6, 7 - 7, 12; tamże 41, SOC fasc. 1, s. 17, 10 - 18, 2. M. Salamon (Rozwój idei Rzymu-Konstantynopola od IV do pierwszej połowy VI wieku, Katowice 1975, 78) zwrócił uwagę, że pogląd o braku tradycji pogańskiej wschodniej stolicy był konsekwencją jej założenia przez chrześcijańskiego władcę, a sama idea w kolejnych wiekach przyczyniła się do wzrostu napięcia między dwoma biskupstwami stołecznymi. 
wać zwierzchnikowi Kościoła w Konstantynopolu, zarządzającemu biskupim tronem „Nowego Rzymu”" ${ }^{6}$, lecz starał się wyjaśnić przyczyny jego wyniesienia. Ponownie więc wskazywał, że Konstantynopol nazywano „Nowym Rzymem"66, a miasto posiadało wewnętrzną organizację z senatem na czele, wzorowaną na dawnej stolicy. Podsumowując swój wywód Sozomen skonstatował, że prawa i przywileje jednakowe były we wszystkim w obu miastach ${ }^{67}$. Jak zatem widać, w opinii historyka, biskup Konstantynopola współuczestniczył w wysokiej godności posiadanej przez biskupa Rzymu. Ponieważ w przekonaniu Sozomena działo się tak nie tylko z woli cesarza Konstantyna, ale także samego Boga, myślę, że nie można wspomnianego wyniesienia sprowadzać wyłącznie do racji politycznych.

Sozomen w swej Historii Kościoła dał o wiele mniej zestawień najważniejszych biskupów niż uczynił to Sokrates. Co ciekawe, na trzy tego typu zestawienia, jakie w ogóle zamieścił w swym dziele, dwa przypadają na panowanie cesarza Konstantyna I. Pierwsze z nich zamieścił niemal na początku swej relacji, kiedy przeszedł, jak to ujął, do „opowiadania wydarzeń”. Wskazał wówczas, że za konsulatu Kryspusa († 326) i Konstantyna władzę w Kościele rzymskim sprawował Sylwester I (314-335), w aleksandryjskim - Aleksander, a w jerozolimskim - Makary. Biskupi tron Antiochii, jak podał Sozomen, od czasu śmierci biskupa Romana nie został obsadzony z powodu prześladowań chrześcijan aż do soboru w Nicei, kiedy to przeniesiono tam

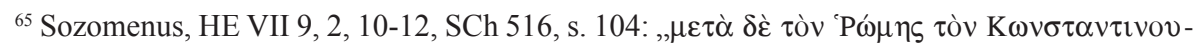

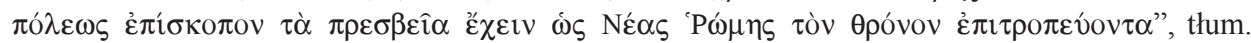
S. Kazikowski, s. 467. E. Stein (Le développement du pouvoir patriarcal du siège de Constantinople jusqu'au Concile de Chalcédoine, „Le Monde Slave” 4:1926, 83) zauważył, iż w kanonie tym przyznano biskupowi Konstantynopola pierwszą rangę po papieżu: ,mais sans ajouter à cette élévation de dignité aucune extension de ses pouvoirs hiérarchiques"; por. też P. Rodopoulos, Primacy of Honor and Jurisdiction (Canons Two and Three of the Second Ecumenical Synod), w: La signification et l'actualité du II Concile Oecuménique pour le monde chrétien d'aujourd'hui, Chambésy - Geneve 1982, 377-384; J. Meyendorff, The Council of 381 and the Primacy of Constantinople, w: La signification, s. 399-413. G. Dagron (Naissance d'une capitale, s. 458), dostrzegając paralelność między kanonami nicejskimi 6 i 7, a konstantynopolitańskimi 2 i 3, doszedł do wniosku, że Konstantynopol został uznany „explicitement «nouvelle Rome»” a ,implicitement «nouvelle Jérusalem»”. W przekonaniu M. Salamona (Rozwój idei Rzymu - Konstantynopola, s. 98) do zastosowania w kanonie określenia „Nowy Rzym”, a nie „Drugi Rzym”, nie należy przywiązywać większego znaczenia, skoro tym drugim tytułem posługiwał się Grzegorz z Nazjanzu (329/330-ok. 390), ówczesny biskup Konstantynopola.

${ }^{66}$ Sozomen podkreśla (HE VII 9, 3, 13, SCh 516, 104, thum. Kazikowski, s. 467), że miasto

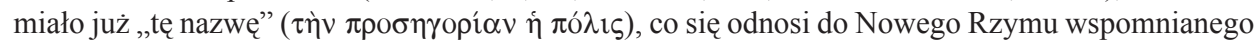
we wcześniejszym zdaniu.

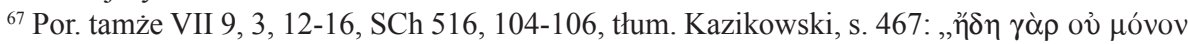

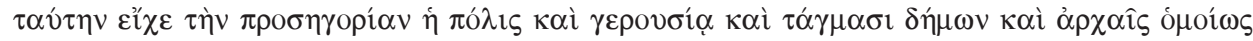

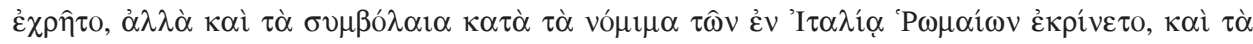

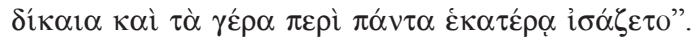


Eustacjusza, biskupa sąsiedniej Beroi ${ }^{68}$. Jak można przypuszczać wymienienie na końcu Antiochii było spowodowane ówczesnym wakatem na urzędzie biskupim tamtejszego Kościoła. Choć Sozomen mógł to także uczynić pod wpływem lektury dzieła Sokratesa, który wydawał się dawać pierwszeństwo biskupowi Jerozolimy przed biskupem Antiochii. W każdym razie wśród czterech najważniejszych Kościołów znajdowała się wspólnota jerozolimska.

Podobną kolejność biskupów zastosował Sozomen opisując wydarzenia, jakie miały miejsce po śmierci cesarza Teodozjusza I, acz z dwoma różnicami - dołączył do zestawienia biskupa Konstantynopola, a biskupa Antiochii przesunął przed biskupa Jerozolimy, jako że w tym czasie tron biskupa antiocheńskiego był już obsadzony. W relacji Sozomena zatem:

„Głową Kościoła rzymskiego był wtedy - po Damazym [366-384] - Syrycjusz [384-399]; Kościołowi konstantynopolitańskiemu przewodził Nektariusz [381-397], aleksandryjskiemu - Teofil [I], a następnie antiocheńskiemu Flawian [381-404], i jerozolimskiemu - Jan [II]"'69.

Kolejność ta została przyjęta przez cesarza Justyniana (527-565), który usankcjonował istnienie pięciu patriarchów w takim właśnie porządku pierwszeństwa: Rzym, Konstantynpol, Aleksandria, Antiochia, Jerozolima ${ }^{70}$.

Zwraca uwagę, że i Sokrates zajmując się tym samym okresem, a więc dziejami Kościoła i państwa po śmierci cesarza Teodozjusza I, podał podobne zestawienie, w którym występują ci sami biskupi. Jedynie na czele Kościoła rzymskiego wymienił zamiast Syrycjusza, jak uczynił to Sozomen, jego poprzednika Damazego. Popełnił jednak błąd, gdyż Damazy już nie żył i zastąpił go właśnie Syrycjusz. Sozomen dostrzegł tę pomyłkę i wprowadził stosowną korektę. Nie była to jedyna różnica między wskazanymi zestawieniami. W tekście Sokratesa biskup Jerozolimy został wymieniony przed biskupem Antiochii, a hierarcha Konstantynopola znalazł się na końcu stawki. Sozomen zatem wprowadził do wykazu przedstawionego przez Sokratesa istotne korekty. Poprawił błąd Sokratesa dotyczący ówczesnego biskupa Rzymu, przeniósł biskupa Konstantynopola na drugie miejsce, zapewne zgodnie z 3. kanonem Soboru Konstantynopolitańskiego I, opisanego przezeń w Historii Kościoła, oraz przesunął biskupa Antiochii przed biskupa Jerozolimy, tego ostatniego wymieniając na końcu. Jak się wydaje zmian tych dokonał świadomie, poprawiając tekst Sokratesa. Jak zatem można przypuszczać, tak oto wyglądała hierarchia najważniejszych stolic biskupich według Sozomena: Rzym, Konstantynopol, Aleksandria, Antiochia, Jerozolima.

Tym bardziej więc zaskakuje zestawienie biskupów, biorących udział w soborze w Nicei w 325 r. podane przez Sozomena. W grupie obecnych

\footnotetext{
${ }^{68}$ Por. tamże I 2, 1-2, SCh 306, 120-122, tłum. Kazikowski, s. 36.

${ }^{69}$ Tamże VIII 1, 1, 6-10, SCh 516, 226, tłum. Kazikowski, s. 518.

${ }^{70}$ Por. Przekop, Wschodnie patriarchaty, s. 35.
} 
na obradach dostojników z siedzib apostolskich, jak zaznaczył historyk, na pierwszym miejscu wymienił on biskupa Jerozolimy, a w następnej kolejności biskupów Antiochii, Aleksandrii i przedstawicieli biskupa Rzymu. Tak znaczne w tym przypadku wyeksponowanie biskupa jerozolimskiego miało związek z zastosowanym przy ustalaniu hierarchii biskupów kryterium ich doboru, którym było apostolskie pochodzenie Kościołów. W tej kategorii żadne z biskupstw nie mogło dorównać jerozolimskiemu. Ostatnie miejsce, na jakim znaleźli się legaci rzymscy, wynikało z nieobecności ich biskupa w Nicei. Sozomen wymienił bowiem najpierw tych, którzy wzięli udział w obradach, by na koniec poinformować, że Sylwester I, biskup Rzymu, nie mógł w nich uczestniczyć z powodu swego sędziwego wieku. Zwraca także uwagę fakt, że biskup Antiochii został tu wymieniony przed biskupem Aleksandrii. Nie da się tego wytłumaczyć inaczej, jak tylko Piotrowym pochodzeniem biskupstwa antiocheńskiego. Wszak pisał o nim już Euzebiusz z Cezarei, a Sokrates, którego dzieło Sozomen dobrze znał, wyrażał podobne przekonanie w odniesieniu do Ignacego $\mathrm{z}$ Antiochii, widząc $\mathrm{w}$ nim trzeciego $\mathrm{z}$ kolei biskupa tamtejszego miasta po Apostole Piotrze ${ }^{71}$.

Wydaje się zatem, że Sozomen odróżniał oficjalną hierarchię biskupów, na której swe piętno odcisnęła zasada akomodacji, od hierarchii związanej $\mathrm{z}$ apostolskim pochodzeniem ich władzy biskupiej.

5. Teodoret z Cyru (ok. 393-460). Dużą wagę do apostolskiego pochodzenia Kościołów przywiązywał także kolejny z historyków Teodoret z Cyru, który często używał w swoim dziele na określenie wspólnot ortodoksyjnych wyrażenia „katolicki i apostolski”, żeby podać tu chociażby przykłady Kościołów w Aleksandrii ${ }^{72}$, czy w Antiochii ${ }^{73}$. Zresztą określenia „,apostolski” używał bardzo często, odnosząc go do wiary, tradycji czy zwyczajów przejętych od Apostołów, i traktując je jako probierz do oceny prawowierności w Kościele. Oznaczało ono jednak dla niego także pochodzenie.

W swej Historii Kościelnej biskup Cyru dwukrotnie zamieścił zestawienia hierarchów najważniejszych stolic biskupich. Za pierwszym razem przystępując do omówienia kontrowersji ariańskiej ${ }^{74}$ wymienił ówczesnych hierarchów kościelnych ${ }^{75} \mathrm{w}$ następującej kolejności: Rzym, Antiochia, Jerozolima, Konstantynopol, Aleksandria. Pojawienie się na końcu tej stawki Aleksandra I, biskupa Aleksandrii, było związane z tokiem narracji Teodoreta, który w następnym rozdziale zamieścił treść listu tegoż biskupa do jego imiennika w Konstantynopolu na temat błędu Ariusza (256-336). Dlatego istotniejsze

\footnotetext{
${ }^{71}$ Por. Socrates, HE VI 8, 11, 36-38, SCh 505, 298, thum. Kazikowski, s. 466.

${ }^{72}$ Por. Theodoretus Cyrensis, HE I 9, 7, 58, SCh 501, 224.

${ }^{73}$ Por. tamże V 9, 16, 146-147, SCh 530, 374.

${ }^{74}$ Por. tamże, I 2, 1-12, 1-69, SCh 530, 144-150.

${ }^{75}$ Por. tamże I 3, 1-3, 1-15, SCh 530, 150-152.
} 
jest drugie zestawienie zamieszczone przez historyka na końcu jego dzieła. Wydaje się, że gruntownie je przemyślał. Zapowiadał wszak Teodoret, że wymieni według porządku ( $\kappa \alpha \tau \grave{\alpha} \tau \alpha \dot{\xi} \xi \mathrm{iv)} \mathrm{biskupów} \mathrm{największych} \mathrm{miast} \mathrm{(} \tau \hat{\omega} v$

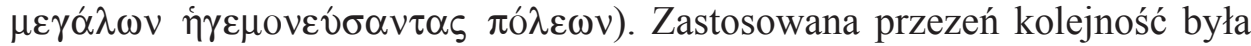
następująca: Rzym, Antiochia, Aleksandria, Jerozolima, Konstantynopol. Co ciekawe w tym wypadku nie podkreślał apostolskości wspomnianych Kościołów. Uczynił tak zapewne ze względu na znajdujący się wśród nich Kościół konstantynopolitański, który nie miał za sobą tak długiej i chwalebnej przeszłości. Znamienne, że został on wymieniony przez Teodoreta na ostatnim miejscu, w przeciwieństwie do Kościoła rzymskiego, od którego rozpoczął wspomniane zestawienie.

Zwraca również uwagę umieszczenie biskupa antiocheńskiego na drugim miejscu przed biskupem Aleksandrii. Oczywiście mogło to wynikać z faktu, że historyk sam związany był z Antiochią. W cytowanym przezeń liście biskupów zebranych na soborze w Konstantynopolu, a adresowanym do biskupów zebranych na synodzie w Rzymie, Kościół antiocheński został nazwany „najstarszym i prawdziwie apostolskim Kościołem [...], w którym po raz pierwszy użyto czcigodnego imienia chrześcijan"76. Wydaje się jednak, że kluczem do zastosowanego przez Teodoreta porządku biskupów było Piotrowe pochodzenie siedzib biskupów wymienionych w pierwszej kolejności. Kościoły w Rzymie i w Antiochii w świadomości ówczesnych, kształtowanej między innymi przez Euzebiusza z Cezarei, zostały założone przez Apostoła Piotra. W Rzymie znajdował się w dodatku jego grób. Fundamenty pod Kościół w Aleksandrii położył z kolei uczeń Piotra - Marek. Wspólnota wiernych w Jerozolimie była zaś jedynie naznaczona obecnością Piotra, gdyż wedle tradycji, choćby tej lansowanej przez wspomnianego już Euzebiusza, ani Apostoł, ani jego uczniowie, nie odgrywali w niej czołowej roli. We wspomnianym już poprzednio liście biskupów zebranych na soborze w Konstantynopolu, cytowanym przez biskupa Cyru, Jerozolima zyskała miano „matki wszystkich Kościołów" "77. Mimo to Teodoret umieścił ją dopiero na czwartym miejscu za Rzymem, Antiochią i Aleksandrią, ale przed Konstantynopolem. Nie zastosował wobec niej zasady akomodacji, gdyż nie odgrywała ona większej roli jako centrum polityczne. Nie kierował się też wobec niej zasadą historyczna, gdyż musiałby jako matkę Kościołów wymienić ją na pierwszym miejscu. Jak się zatem wydaje, zadecydowała tu zasada Piotrowego pochodzenia. Tak więc Teodoret ustalając porządek poszczególnych Kościołów zastosował najprawdopodobniej podwójne kryterium. Odwołał się do zasady akomodacji, kiedy mówił o biskupach w największych miastach, oraz do zasady Piotrowego pochodzenia biskupstw, tę ostatnią uważając za ważniejszą, skoro wymienił Jerozolimę przed Konstantynopolem.

\footnotetext{
${ }^{76}$ Tamże V 9, 16, 146-148, SCh 530, 374, tłum. własne.

${ }^{77}$ Tamże V 9, 17, 154-155, SCh 530, 374, tłum. własne.
} 
Jak zatem widać, piszący w IV wieku Euzebiusz z Cezarei, hierarchizując biskupów kierował się przede wszystkim zasadą akomodacji. W przypadku historyków tworzących wiek później zasada ta wydaje się mieć już zdecydowanie mniejsze znaczenie. Przekaz Filostorgiusza, jako fragmentaryczny, trudny jest co prawda do interpretacji, ale w podejściu Sokratesa widoczna jest już wyraźnie zasada apostolskiego pochodzenia, choć najpewniej przejęta od Rufina z Akwilei. Sozomen odróżniał oficjalną hierarchię biskupów, opartą na zasadzie akomodacji, od hierarchii wynikającej z apostolskiego pochodzenia poszczególnych biskupstw. Natomiast Teodoret łączył obydwie zasady, dając wyraźną przewagę Piotrowemu pochodzeniu Kościołów, a więc zasadzie apostolskiego pochodzenia. Wydaje się zatem, wbrew przekonaniu F. Dvornika, że autorzy Historii kościelnych z V wieku w precedencji biskupów wynosili zasadę apostolskiego pochodzenia Kościołów nad zasadę akomodacji.

\section{THE HIERARCHY OF EASTERN BISHOPS IN THE ECCLESIASTICAL HISTORIOGRAPHY OF THE FIFTH CENTURY}

\section{(Summary)}

Francis Dvornik has expressed the view that, in the Eastern part of the Empire, the principle of accommodation dominated over the principle of the apostolic origin. The situation, he maintained, resulted from the fact that the aforementioned area included excessively numerous sees which were either established by one of the Apostles or were considered to be somehow connected with their activities.

Does the conclusion of the Czech researcher find any justification in the way the precedence of bishoprics is depicted in the Greek ecclesiastical historiography of the fifth century? The present article is to give an answer to the question.

The analysis of the ecclesiastical historiography in question demonstrates that Eusebius of Caesarea, who wrote in the IV th century, while setting a hierarchy of bishops was guided first and foremost by the principle of accommodation. The church historians, however, who compiled their works a mere century later put a decisively lesser stress on Eusebius' predilection in that matter. Although the narrative of Philostorgius, since fragmentary, is hard to interpret, Socrates' attitude displays a marked tendency of favoring the importance of the apostolic origin, which was most probably taken over from Rufinus of Aquileia. Sozomen tended to tell the difference between the official hierarchy of bishops, which was based on the principle of accommodation, and the structure of bishoprics connected with the Apostles. Theodoretus, in turn, tended to connect both the principles, however, preferring the idea of the Church originated by saint Peter, accordingly of the ecclesiastic structure based on the principle of the apostolic origin.

As a consequence, and contrary to F. Dvornik's thesis, it should be concluded that (at least) the authors of the Ecclesiastic Histories of the fifth century were in 
favor of the principle of the apostolic origin and maintained it was over the principle of accommodation. 
